\title{
1. Why we should study entrepreneurship addiction
}

\subsection{HISTORY'S POSITIVE FRAME}

Until recent times, the mass media and academic literature have almost exclusively highlighted the positive outcomes of entrepreneurship. ${ }^{1}$ Perhaps this is due to the historical notions of entrepreneurship as a key component of the "American Dream." In support of this perspective, there are several important and meaningful positive outcomes that have been linked to entrepreneurial pursuits. Specifically, entrepreneurs are often found to have higher levels of autonomy-feelings of freedom and independence (Benz \& Frey, 2008; Carter et al., 2003; Shir, 2015), higher job satisfaction (Lange, 2012), higher life satisfaction (Binder \& Coad, 2013), higher psychological capital (Foo et al., 2009), more earnings potential (Markman \& Baron, 2003), higher personal well-being (Hahn et al., 2012), better work-life balance (Ezzedeen \& Zikic, 2017), alignment of their businesses with their sense of purpose, talents, and passions (Shir et al., 2019), and more.

Additionally, at the societal level, entrepreneurship is often credited as the agent of Schumpeter's creative destruction (1942/1976), reinventing and modernizing waning industries and stagnating business models. Furthermore, quality of life improvements are often tied to higher levels of entrepreneurship in a society. In sum, the message is that more entrepreneurship equals a more prosperous and healthier society (Agarwal et al., 2007; Baumol \& Strom, 2007; Hitt 
et al., 2011). It is no surprise that given the largely positive admiration and feelings for the accomplishments tied to entrepreneurship, the most successful entrepreneurs receive considerable media attention, including being featured in Hollywood movies (i.e., Mark Zuckerberg in The social network (released in 2010) and Steve Jobs in Jobs (released in 2013) and Steve Jobs (released in 2015)). The resounding message is that entrepreneurship is the ideal path by which an individual may create a prosperous life.

Much of scholarly attention has echoed this perspective. For example, research has focused on successful entrepreneursidentifying relevant personality traits (Schmitt-Rodermund, 2004), social network characteristics (Aldrich \& Zimmer, 1986), motivations (Johnson, 1990), attitudes (Robinson et al., 1991), and prior experiences (Shane, 2000) to facilitate the recognition of these individuals. Additionally, researchers have sought to make entrepreneurship more accessible to all, by unpacking the key steps in the entrepreneurial process (Shane, 2003), so that anyone may replicate it and pursue such endeavours (Chell, 2013). In an effort to increase the rates of entrepreneurship at a geographic level, there are a variety of support structures, including, but not limited to, government grants, small business development centres and business incubators, and increasing numbers of entrepreneurship programs offered at universities.

\subsection{BALANCING THE PERSPECTIVE}

Recently, however, and in contrast to these overwhelmingly positive messages around entrepreneurship, a variety of negative outcomes and correlates of entrepreneurship are being recognized. With a full inventory of such negative outcomes and correlates, it may be the case that they are as likely or as numerous as the positives, but have simply been given significantly less attention. For example, at the individual level, researchers have found that entrepreneurs tend to have more 
stress and strain (Cardon \& Patel, 2015), more work-life conflict (Prottas \& Thompson, 2006), more role conflict (Rahim, 1996), and more negative health consequences (Cardon \& Patel, 2015) than individuals not pursuing entrepreneurship.

It is also likely that both positive and negative outcomes and correlates can occur concurrently, for the same individuals, or that they can reflect highly heterogeneous experiences that mirror the heterogeneity amongst the entrepreneurs themselves. Moreover, both sets of results can be simultaneously accurate reflections of underlying phenomena; correlational studies operate on the assumption of trends and averages. Hidden by such analyses are all the variations in individual experiences, types of entrepreneurship, interactions between an assortment of variables, and their links to a range of outcomes (Woodside, 2013). Supporting this assessment, qualitative examinations into the lives of individual entrepreneurs on a case basis have revealed variety in the experiences and outcomes of entrepreneurs. For example, in Spivack and Desai (2016), women entrepreneurs express varying assessments of the influence of entrepreneurship on worklife balance-some reported negative outcomes while others reported positive outcomes. Therefore, it is likely the case that neither finding is (in)correct, but rather, there are some individuals for whom entrepreneurship is net negative, when considering a variety of outcomes and/or correlates (Santarelli \& Vivarelli, 2007).

The shift in perspective from a positive framing to a more neutral one, by considering these negative cases, provides a more balanced consideration of entrepreneurship. Instead of a universally positive view of the pursuit, attention can be redirected to the variety of pros and cons of entrepreneurship. Furthermore, we can take a more nuanced view of the individuals and context and say that entrepreneurship can be good or bad-ultimately, it depends. 


\subsection{ATTENTION TO THE EXTREMES}

When studying a new phenomenon, it is useful to consider the outliers or extreme members of the group. In considering which entrepreneurs might suffer the most negative effects of entrepreneurial engagement, one needed to ask, "Why would any entrepreneur persist as an entrepreneur if entrepreneurial acts caused them ill effects?" From that question, entrepreneurship addiction seemed to present a possible explanation. Then, the question became, how would an addiction to entrepreneurship form? This question is explored in depth in Chapter 2 (Spivack et al., 2014).

Specifically, Chapter 2 focuses on characterizing entrepreneurial experience elements that are similar in nature to other behaviours that have addictive qualities. Procedurally, we needed to disentangle and identify cognitive, emotional, and physiological dimensions of the venture creation and growth experiences. This helped to identify what would serve as the basis for the formation of an addiction to entrepreneurship. In doing so, we brought attention to entrepreneurs as living organisms - that is, that people who become entrepreneurs are not just cognitive and emotional (where most of the research had focused), but also have physiological and health reactions to their engagement with entrepreneurial ventures. The consideration of the physiological side of entrepreneurship was a less-studied component at the time. Now, we see researchers studying specific aspects of health and well-being, sleep, physical disorders, etc. in entrepreneurs. In the same chapter, we examine the unfolding of the manifestation of an addiction and the symptoms by discussing two cases in serial, or habitual, entrepreneurs. Chapter 2 represents the launch of a new stream of research in the area of psychological disorders as related to entrepreneurial pursuits. It spawned a growing research area in other psychological "disorders" in entrepreneurship, specifically in areas of ADHD/ADD, bipolar disorder, obsessive compulsive behaviour disorder, 
and more. Attention is now focused on the chicken versus the egg phenomenon-which comes first: the entrepreneur with certain psychological "disorders" that finds entrepreneurship because other work arrangements are less of a person-job fit, or does entrepreneurship foster the development or exacerbation of psychological "disorders"? Regardless, entrepreneurship may confer some advantages to an individual with certain psychological "disorders" while also offering some individual agency in designing a work dynamic that is uniquely tailored to the skills and abilities of an individual entrepreneur with or without a psychological "disorder." This is an exciting avenue to continue exploring.

We took some of these ideas around work patterns and proposed them as the basis for situating entrepreneurship addiction among other related entrepreneurship constructs. Specifically, in Chapter 3 (Spivack \& McKelvie, 2018a), we wanted to distinguish and position entrepreneurship addiction among topics like workaholism, work engagement, obsessive and harmonious passion, and burnout. We spend much time explaining how entrepreneurship is a special work context that intensifies qualities of typical employment arrangements, such that notions of workaholism are related but insufficient to characterize work patterns of addicted entrepreneurs. This was an important theoretical discussion that helped to further the distinctiveness of entrepreneurship addiction from sister concepts, but also to propose a set of relationships to guide future research in this area.

Then, we wanted to identify how to measure entrepreneurship addiction to help answer questions such as "what is the prevalence rate of entrepreneurship addiction among entrepreneurs?" and "who is most likely to show symptoms of entrepreneurship addiction?" These questions are attended to in Chapter 4 (Spivack \& McKelvie, 2018b). This chapter builds upon the conceptual relationships and ideas that we bring to light in Chapter 3. However, the biggest areas of contribution in this chapter are in the empirical operation- 
alization of the key ideas presented in Chapters 1 and 2, as well as the empirical evidence about the relationships that we had identified and discussed throughout the earlier chapters. Finally, we end the book with Chapter 5, which provides some avenues for future research to further this important stream. This chapter builds upon the insights and ideas that we shared in the other chapters, as well as greater reflection about some of the opportunities and challenges we faced, especially in terms of the empirical operationalization work. Overall, we hope that the book presents a story of how our scholarly work has evolved from a set of empirical observations among a select group of habitual entrepreneurs, to greater conceptual development and framing within a number of well-established concepts, to a broader-scale empirical examination of hundreds of entrepreneurs with a variety of backgrounds, and to charting a research agenda to guide the further evolution for studying this topic.

\section{NOTE}

1. This chapter includes new content and excerpts from Spivack, A.J. (2020). Entrepreneurship addiction and the negative mental health consequences of entrepreneurial engagement among some entrepreneurs. In A. Örtenblad (Ed.) Against entrepreneurship: A critical examination. London: Palgrave Macmillan. Reproduced with permission of Palgrave Macmillan.

\section{REFERENCES}

Agarwal, R., Audretsch, D., \& Sarkar, M.B. (2007). The process of creative construction: Knowledge spillovers, entrepreneurship and economic growth. Strategic Entrepreneurship Journal, 1(2), 263-286.

Aldrich, H., \& Zimmer, C. (1986). Entrepreneurship through social networks. In D. Sexton \& R. Smilor (Eds) The art and science of entrepreneurship (pp. 3-23). Cambridge, MA: Ballinger.

Baumol, W.J., \& Strom, R.J. (2007). Entrepreneurship and economic growth. Strategic Entrepreneurship Journal, 1(1/2), 233-237. 
Benz, M., \& Frey, B. (2008). Being independent is a great thing: Subjective evaluations of self-employment and hierarchy. Economica, 75(298), 362-383.

Binder, M., \& Coad, A. (2013). Life satisfaction and self-employment: A matching approach. Small Business Economics, 40(4), 1009-1033.

Cardon, M., \& Patel, P.C. (2015). Is stress worth it? Stress-related health and wealth trade-offs for entrepreneurs. Applied Psychology, 64(2), 379-420.

Carter, N.M., Gartner, W.B., Shaver, K.G., Gatewood, E.J. (2003). The career reasons of nascent entrepreneurs. Journal of Business Venturing, 18(1), 13-39.

Chell, E. (2013). Review of skill and the entrepreneurial process. International Journal of Entrepreneurial Behaviour and Research, 19(1), 6-31.

Ezzedeen, S.R., \& Zikic, J. (2017). Finding balance amid boundarylessness: An interpretive study of entrepreneurial work-life balance and boundary management. Journal of Family Issues, 38(11), 1546-1576.

Foo, M.-D., Uy, M.A., Baron, R.A. (2009). How do feelings influence effort? An empirical study of entrepreneurs' affect and venture effort. Journal of Applied Psychology, 94(4), 1086-1094.

Hahn, V.C., Frese, M., Binnewies, C., Schmitt, A. (2012). Happy and proactive? The role of hedonic and eudaimonic well-being in business owners' personal initiative. Entrepreneurship Theory and Practice, 36(1), 97-114.

Hitt, M.A., Ireland, R.D., Sirmon, D.G., Trahms, C.A. (2011). Strategic entrepreneurship: Creating value for individuals, organizations, and society. Academy of Management Perspectives, 25(2), 57-75.

Johnson, B.R. (1990). Toward a multidimensional model of entrepreneurship: The case of achievement motivation and the entrepreneur. Entrepreneurship Theory and Practice, 14(3), 39-54.

Lange, T. (2012). Job satisfaction and self-employment: Autonomy or personality? Small Business Economics, 38(2), 165-177.

Markman, G.D., \& Baron, R.A. (2003). Person-entrepreneurship fit: Why some people are more successful as entrepreneurs than others. Human Resource Management Review, 13(2), 281-301.

Prottas, D.J., \& Thompson, C.A. (2006). Stress, satisfaction, and the work-family interface: A comparison of self-employed business owners, independents, and organizational employees. Journal of Occupational Health Psychology, 11(4), 366-378. 
Rahim, A. (1996). Stress, strain, and their moderators: An empirical comparison of entrepreneurs and managers. Journal of Small Business Management, 34(1), 46-58.

Robinson, P.B., Stimpson, D.V., Huefner, J.C., Hunt, H.K. (1991). An attitude approach to the prediction of entrepreneurship. Entrepreneurship Theory and Practice, 15(4), 13-31.

Santarelli, E., \& Vivarelli, M. (2007). Entrepreneurship and the process of firms' entry, survival and growth. Industrial and Corporate Change, 16(3), 455-488.

Schmitt-Rodermund, E. (2004). Pathways to successful entrepreneurship: Parenting, personality, early entrepreneurial competence, and interests. Journal of Vocational Behavior, 65(3), $498-518$.

Schumpeter, J.A. (1942/1976). Capitalism, socialism and democracy (3rd edn). New York: Harper Torchbooks.

Shane, S. (2000). Prior knowledge and the discovery of entrepreneurial opportunities. Organization Science, 11(4), 448-469.

Shane, S. (2003). A general theory of entrepreneurship. Cheltenham, UK and Northampton, MA, USA: Edward Elgar Publishing.

Shir, N. (2015). Entrepreneurial well-being: The payoff structure of business creation. PhD thesis. Stockholm: Stockholm School of Economics. https://ex.hhs.se/dissertations/849175-FULLTEXT02 .pdf.

Shir, N., Nikolaev, B.N. Wincent, J. (2019). Entrepreneurship and well-being: The role of psychological autonomy, competence, and relatedness. Journal of Business Venturing, 34(5), 105875.

Spivack, A.J., \& Desai, A. (2016). Women entrepreneurs' workfamily management strategies: A structuration theory study. International Journal of Entrepreneurship and Small Business, 27(2/3), 169-192.

Spivack, A.J., \& McKelvie, A. (2018a). Entrepreneurship addiction: Shedding light on the manifestation of the "dark side" in work-behavior patterns. Academy of Management Perspectives, 32(3), 358-378.

Spivack, A.J., \& McKelvie, A. (2018b). Measuring addiction to entrepreneurship and testing links to well-being. Paper presented at the Academy of Management Annual Meeting, August 10-14, Chicago, IL.

Spivack, A.J., McKelvie, A., Haynie, J.M. (2014). Habitual entrepreneurs: Possible cases of entrepreneurship addiction? Journal of Business Venturing, 29(5), 651-667.

Woodside, A.G. (2013). Moving beyond multiple regression analysis to algorithms: Calling for a paradigm shift from symmetric to 
asymmetric thinking in data analysis, and crafting theory. Journal of Business Research, 66(4), 463-472. 